University of Windsor

Scholarship at UWindsor

7-2009

\title{
Using the I-MARKOR scale to identify market-oriented individuals in the financial services sector
}

Francine K. Schlosser

Odette School of Business, University of Windsor

Rod McNaughton

Follow this and additional works at: https://scholar.uwindsor.ca/odettepub

Part of the Business Commons

\section{Recommended Citation}

Schlosser, Francine K. and McNaughton, Rod. (2009). Using the I-MARKOR scale to identify marketoriented individuals in the financial services sector. Journal of Services Marketing, 23 (4), 236-248. https://scholar.uwindsor.ca/odettepub/119

This Article is brought to you for free and open access by the Odette School of Business at Scholarship at UWindsor. It has been accepted for inclusion in Odette School of Business Publications by an authorized administrator of Scholarship at UWindsor. For more information, please contact scholarship@uwindsor.ca. 


\title{
Using the I-MARKOR Scale to Identify
}

\section{Market-oriented Individuals in the Financial Services Sector}

\author{
Francine K. Schlosser \\ University of Windsor \\ Windsor, Ontario, Canada \\ Rod B. McNaughton \\ University of Waterloo, \\ Waterloo, Ontario, Canada
}

Correspondence to:

Francine K. Schlosser, Ph.D.

Assistant Professor, Management

Odette School of Business

University of Windsor

Windsor, ON

N9B 3P4

Email: fschloss@uwindsor.ca

Phone: (519) 253-3000 ext. 3107

Key Words: Market Orientation, MARKOR, Scale Development, Dynamic Capabilities, Financial Services

Categorization: $\quad$ Research Paper

CITATION: Schlosser, FK; McNaughton, R., Using the I-MARKOR Scale to Identify Market-oriented Individuals in the Financial Services Sector, Journal of Services Marketing, 4(23), 235-246, 2009. 


\section{Author Biographies}

Dr. Francine Schlosser (fschloss@ uwindsor.ca) is an Assistant Professor in the Odette School of Business at the University of Windsor, Canada. Her research focuses upon the contribution of the individual to the development and implementation of a firm's strategic orientation.

Dr. Rod McNaughton (rmcnaughton@uwaterloo.ca) holds the Eyton Chair of Entrepreneurship in the Department of Management Sciences at the University of Waterloo, Canada. He is also is the Director of the Institute for Innovation and the CoDirector of the Centre for Business, Entrepreneurship and Technology. 


\begin{abstract}
Purpose: Extant studies of the market orientation of service firms rarely consider the contribution of individual employees to the realization of this orientation. Existing scales that measure market orientation reveal the perceptions of a key informant about the dominant orientation within the firm. These scales do not measure the willingness of employees to act in a market-oriented way. This paper reports the development of a multi-dimensional scale of individual market-oriented behavior.

Methodology: The scale development process included identification of items from focus groups with employees of a major Canadian financial services firm and the market orientation literature. A pretest with marketing practitioners and academics helped to purify and reduce the number of items. Finally, a sample of North American financial services employees responded to the items in a web-based questionnaire.

Findings: Confirmatory factor analysis of the responses confirmed the presence of a single latent construct with three dimensions: information acquisition, information sharing and strategic response, measured by 20 items.

Research Implications/Limitations: Although scale validation included both qualitative and quantitative tests that triangulated the opinions of multiple stakeholders in the service delivery chain, future research must also test the predictive validity of this scale.

Practical Implications: Such research is important to increase understanding of how service organizations foster market orientation. The I-MARKOR augments the organizational scorecard approach with individual level measurement.

Originality/Value of Paper: This scale provides a method to assess differences between individuals within an organization, enabling empirical research on differences between departments, roles, training and other characteristics that may influence the extent to which an individual performs market-oriented behaviors.
\end{abstract}




\section{Running Head: Developing the I-MARKOR}

\section{Measuring the Contribution of Individuals to Market-Orientation: The I-MARKOR scale}

\section{INTRODUCTION}

Market-oriented firms 'seek to understand customers' expressed and latent needs, and develop superior solutions to those needs" (Slater and Narver 1999, p. 1165). A firm's market orientation builds upon three dimensions: the organization-wide acquisition, dissemination, and co-ordination of market intelligence (Jaworski and Kohli 1993). This involves policies and competencies necessary to obtain key strategic information, as well as the internal communication networks for sharing the information, and creating a strategic response. In order to develop a market orientation strategy, firms must convince employees to "buy-into" the concept (Piercy et al. 2002). Identifying and sustaining customer focused service quality is a critical strategic dimension for services organizations and is related to the interaction between buyer and seller and resulting outcomes (Ballantyne et al. 1995). The building of a quality focused production orientation is based upon employee market-oriented behavior. If organizations are unable to build awareness, ability and motivation to act in market-oriented ways, they may face employee resistance and eventual failure of market-oriented initiatives (Harris 2002). Employees throughout the company contribute varied information about the market that can create competitive advantage. Thus, understanding how employees define and view market-oriented behaviors is a key to successfully fostering a market orientation. 
The importance of market orientation for competitive advantage and financial performance is a central theme in contemporary marketing literature. However, the focus of this literature, both in terms of theory and the unit of empirical observation, is the organization rather than the individuals within the organization (e.g., Farrell 2000; Han et al. 1998; Jaworski and Kohli 1993; Narver and Slater 1990). This concentration on the firm level construct ignores the underlying routines performed by individuals that develop and form the orientation (Nelson and Winter 1982). Individuals throughout the organization contribute to organization level market-orientation through actions such as fostering internal and external relationships (Helfert et al. 2002), modeling behavior and social influence (Fulk 1993; Wood and Bandura 1989), communicating tacit knowledge (Darroch and McNaughton 2003). Market oriented routines are especially important to service-based firms, because they develop key service competencies in buyer-seller relationships and interdependence (Webster 1978), and service reliability (Caruana et al. 2003). Market oriented routines also provide a way to understand and exploit the many intangibles associated with effective service delivery.

Seminal contributors to the literature on market orientation hold different views on how organizations foster a market orientation. For example, Narver (1990) cites the internalization of core customer-oriented values by individual employees. Jaworski and Kohli (1993) suggest market orientation is built through downward influence from employer to employee, and Farrell (2000) argues that market orientation is the result of both planned and emergent change strategies. All are likely mechanisms. However, previous market orientation studies inadequately measure this individual contribution to 
the market orientation of a firm. In the service sector, it is critical to understand and meet the long-term needs of customers through effective employee-customer interaction. Despite this, almost all scales measure market orientation at an organizational or SBU level of analysis and do not recognize the personal responsibility and willingness of employees to act in market-oriented ways. Respondents describe the general level of market orientation perceived to be present across their organization, not how they themselves act. Additionally, scales that measure market orientation, like the widely used MARKOR, only reveal the perception of a single key informant of the state of marketoriented characteristics within an organization. For example, most market orientation research reflects only the opinions of senior marketing or other managers (e.g., Kennedy et al. 2002; Van Egeren and O'Connor 1998). However, the competitive advantage of service organizations relies upon strong, customer-oriented services provided by individuals throughout the organization. While senior managers have a role in fostering a market orientation within their organization, reliance on their opinion hides varying perspectives within the organization. Management and employees may hold dissimilar viewpoints, and differences in training, responsibilities, and experiences. Kahn (2001) suggests there may also be differences between departments, for example between R\&D and marketing areas.

The financial services industry has experienced many changes in recent years, with mergers and acquisitions creating greater job instability. In spite of these changes, only a few studies have considered the role of market orientation in financial services (Bhuian 1997) or specifically financial distribution channels (Thornton and White 2001) and none that link the market knowledge of individuals employed throughout a financial 
services organization. Market research drives market orientation and performance in service firms (Van Egeren and O'Connor 1998), and there is a need for more research to expand the market orientation concept from product marketer to service provider (Javalgi et al. 2005).

In sum, the market orientation literature currently offers little understanding of market-oriented perspectives and behaviors of individuals within service organizations. An impediment to empirical research on this issue is the lack of a scale to measure the market orientation of individuals. The Customer Mind-Set scale (CMS) developed by Kennedy et al. (2002), is an example of a scale that is designed to assess the extent to which an individual employee posses the characteristics associated with a particular "mind-set". The concept of an employee having a "customer mind-set" is likely related to an employee behaving in a market-oriented way, but Kennedy et al. do not test this proposition. The CMS scale does not include dimensions of market orientation such as competitor focus and information sharing. CMS is an important analogous scale, but is not a measure of the market orientation of an individual.

In response, this study targets two main research objectives: (1) identifying the market-oriented behaviors of individuals employed in service-based organizations, and (2) developing and testing the psychometric properties of a scale of individual marketoriented behaviors in a financial services context. 


\section{THE INDIVIDUAL MARKET ORIENTATION CONSTRUCT}

Kohli and Jaworski (1990) defined market orientation as "the organization-wide generation of market intelligence pertaining to current and future customer needs, dissemination of the intelligence across departments, and organization-wide responsiveness to it" (Jaworski and Kohli 1993, p.54). Market orientation can be positioned within the Resource-based View of the Firm (RBV), which focuses on internal resource arrangements and firm value creation. Adherents of the RBV conceptualize firms as bundles of resources, heterogeneously distributed across firms, with persistent differences (Eisenhardt \& Martin, 2000; Penrose, 1959; Wernerfelt, 1984). Bell (1973) argued that market-oriented behaviors provide information resources that are important to a firm's success.

Building on RBV, Eisenhardt and Martin (2000) suggested that resource functionality can be duplicated, so the real value for competitive advantage lies in the arrangement of resources. The dynamic nature of this arrangement provides sustainable competitive advantage and is widely discussed in the Dynamic Capabilities branch of RBV literature (Lei et al. 1996; Teece et al. 1997; Winter 2000). Eisenhardt and Martin (2000, p. 1107) defined dynamic capabilities as “The firm's processes that use resources - specifically the processes to integrate, reconfigure, gain and release resources - to match and even create market change." As a dynamic capability, the focus of market orientation on internal information sharing contributes to firm value by integrating resources through inter-functional co-ordination and information sharing routines. 
Despite some discussion of market orientation as a firm capability (Day 1994), the literature does not adequately reflect potential fit within the resource-based view of the firm (RBV), specifically as a dynamic capability. Neither is it well-reflected in the services view of marketing even though the latter pledges in principle to "identify or develop core competences, the fundamental knowledge and skills of an economic entity that represent potential competitive advantage"(Vargo and Lusch 2004, p. 5)

This study adapts Kohli and Jaworski's (1990) definition of organizational market orientation to reflect characteristics of individual employees. Thus, the market orientation of individuals reflects the attitudes and behaviors of employees as they acquire, share, and respond to market intelligence. For instance, Kohli and Jaworski measure a participant's perception of the organization's market orientation by using words such as "In this organization" or "we" in their items. A full list of their items is included in the Appendix. To date, there has been little consideration of market orientation from the perspective of the individual employee (or the "I"). Subsequent discussion of the construct domain will build upon definitions and measures at the organizational level.

Organizational Level Domain. Current scales, measuring market orientation at the organizational level, inform this research. The literature contains diverse definitions and measures of market orientation. The two most prominent measures are the MARKOR scale (Kohli et al. 1993) and the MKTOR (Narver and Slater 1990). Both are more than ten years old. Subsequent scale development relied substantially on these two seminal scales and did not reflect significant advancement of the theory (Farrell 2000). This 
inertia may actually reflect a consensus amongst researchers on the domain of the construct. That is, the market orientation construct may be viewed as a combination of both the breadth of its coverage (including general market focus) and the depth of its coverage (the three behavioral dimensions of collecting, disseminating and sharing/responding to information).

Breadth. Researcher consensus has helped to differentiate market orientation from other related strategic orientations. Market orientation at an individual level consists of practices oriented toward the customer, competitor and other aspects of the external market. In general the research community considers a profit orientation to be an outcome of a market orientation (Farrell 2000). Most researchers do not accept Deng and Dart's (1994) extension of the domain of the construct to include a profit emphasis. A profit orientation is not externally focused; instead, it considers the internal play of resources and rents. Additionally, the market orientation domain does not extend to a learning orientation because it does not focus upon new learning and evolution of strategies, nor to a knowledge management orientation and internal relationship marketing because market orientation focuses upon acquisition of knowledge external to the firm. Thus, the domain is well bounded from those of allied concepts in the literature.

Depth. There seems to be general agreement that market orientation should include aspects of customer and competitor orientation, and a sharing of information. The most frequently used operationalizations of market orientation are behaviorally based 


\section{Running Head: Developing the I-MARKOR}

(e.g., Kohli et al. 1993; Narver and Slater 1990) or at least contain subcomponents of behaviors (e.g., Homburg and Pflesser 2000).

Recent construct development has also focused upon behaviors, or more specifically, relationship management tasks (Helfert et al. 2002), although measured with low reliability $(\alpha=.68)$. The relationship management tasks included in Helfert et al. (2002) reflect the value marketing places in customer and inter-organizational relationships. Market orientation is a construct measuring external focus, and internal coordination of such externally focused values and behaviors. Thus, relationship management skills represent an important part of the inter-functional coordination or knowledge sharing, and contribute implicitly to the firm and employee's abilities to acquire and disseminate information.

Individual Level Construct Domain. The individual level market-orientation construct builds from the domain established for the organizational level. There is a need to measure behaviors at an individual level because employees must take responsibility to build firm market orientation through their own actions. Previous research indicates that individual employee attitudes and behaviors relate to an organization's market orientation (e.g., Celuch et al. 2000; Harris and Ogbonna 2001; Langerak 2001). As individual attitudes and actions help to shape and develop an overall market orientation, organizations must clearly understand the influence of individual and interpersonal factors. 
Individual level market-orientation originating from individual differences. At the organizational level, learning orientation has been connected to market orientation (Baker and Sinkula 1999; Farrell 2000; Liu et al. 2002; Slater and Narver 1995). In theory, this supports a connection at the individual level because a learning organization is built upon the interaction between individuals within the organization (Cho 2002), and the exchange of knowledge (West and Meyer 1997). The learning agility of individuals "is characterized by a desire to increase one's competence by developing new skills and mastering new situations" (Bell and Kozlowski 2002, p. 498) and is essential to the evolution of organizations and people (Perkins 1994; Williams 1997).

Individual level market-orientation originating from interpersonal factors. Strong interpersonal exchanges cause individuals to exchange resources and learn from each other, thus reconfiguring and renewing their own knowledge-based routines (Zollo and Winter 2002). Accordingly, the degree of customer contact experienced by employees is anticipated to positively influence the extent of market-oriented actions. Its inclusion is pivotal to understanding how market-oriented behaviors translate throughout an organization. Previously, few studies included such a focus, preferring to target marketing and senior management teams. The few that considered differences across business functions contrast marketing with operations in manufacturing firms (e.g., Kahn 2001) or focus on those with close customer contact in studies of sales force and customer orientation (e.g., Harris 2000; Langerak 2001). 
This section has linked the value of the individual market orientation construct to organizational level research and considered its relationship with potential individual and interpersonal level factors.

\section{MEASURING INDIVIDUAL MARKET ORIENTATION}

This research develops the I-MARKOR measure of individual level market orientation using Churchill's (1979) measure development process. Encouraged by the greater use of structural equation modeling in data analysis, Churchill's approach is widely used in the marketing literature in spite of its heavy reliance on data over theory (Rossiter 2002). However, Churchill's focus upon Cronbach's Alpha creates problems when developing a multidimensional, emergent construct (Rossiter 2002). Therefore other researchers advocate even greater use of factor analysis and structural equation modeling (e.g., Gerbing and Anderson 1988). In this study Cronbach's Alpha and exploratory factor analysis are used simultaneously to make more complete decisions about item retention or elimination (Flynn and Pearcy 2001). The scale is also reviewed for validity by practitioner and academic experts, as recommended by Hardesty and Bearden (2004). Thus, this research builds upon Churchill's method and includes improvements in the process recommended by others.

This section of the paper outlines the scale development process and presents data supporting the reliability and validity of the I-MARKOR scale. 
Generation of Scale Items

Initial items (71 items) were generated with guidance from the extant market and customer orientation literatures, as well as knowledgeable academics and practitioners. Having differentiated the individual level construct from the organizational level construct, and based upon the conceptualization considered in the previous section, the construct was hypothesized to be a three-dimensional construct at the individual level. Items from the two seminal organizational-level market orientation measures (Kohli et al. 1993; Narver and Slater 1990) and individual level customer orientation (Brown et al. 2002; Kennedy et al. 2002) and relationship measures (Helfert et al. 2002) were included.

We modified items if they contained terms that could be interpreted differently by employees in different organizational areas. Items from the scales were rephrased to reflect individual level market orientation. For example, "In this business unit, we do a lot of in-house market research." was replaced with "My actions stimulate in-house market research.”

An exploratory study was undertaken with a large Canadian-based financial services company that had recently launched a market-oriented relationship strategy targeted at their distributors. In this industry, distributors play an important part in the consumer buying decision because consumers rely on the agents' expert advice to make product and company choices. Information obtained through twelve executive interviews and five employee focus groups (including employees at all levels and functions of the organization) augmented the content of the items. 
Market orientation at the individual level involved many different employee behaviors specific to a task or role. When assessing the market-oriented aspects of each behavior, respondents often offered examples that could fit within multiple dimensions of market orientation. Market-oriented behaviors identified in the focus groups and interviews reflected both formal (proscribed and scheduled) and informal behaviors within the control of the individual. This list was compared and integrated with the list generated from previous research.

The final stages of qualitative data collection from practitioners involved interviews with 10 distributors across Canada. Their input established the value of different market-oriented behaviors to target "customers", who were in this case, distributors. The inclusion of customer opinion in the development of items is a key element of a "market-oriented" approach to measure development (Harris 2003) and allows for data triangulation. Thus, questions regarding interaction with both the distributors and the premium-payers were included in the item content. By obtaining distributor, employee and management opinions in the exploratory study, we were able to triangulate our findings, and identify themes common among the stakeholders.

Phase 1 Data Collection and Scale Purification

The original list of scale items was reviewed to ensure that it captured items and topics raised in these interviews and focus groups and reinforced content validity. The 
review did not result in a larger measure because the 71-item measure already encompassed the behaviors discussed by focus groups. However, as no items were discarded in this stage, the measure remained quite large and potentially nondiscriminating. Therefore, the scale was exposed to various purification procedures.

Purification Pretest \#1: Industry Practitioners. Participants in the original employee focus groups and interviews screened the 71 scale items. Participants included 28 representatives from various sales and support functions and many different jobs and levels. At the close of each focus group session, participants were presented with the list of scale items and asked: "If you were trying to measure a person's market orientation, which items would you include? Maybe include? Not include?" Respondents were given 20 minutes to note their preferences on the hard copy of the list. They were also encouraged to note suggestions to improve wording or include additional items.

Responses were analyzed for inter-rater agreement using the "sumscore" method advocated by Hardesty and Bearden (2004). Information was collected from executive, middle management and non-supervisory employees. This diversity of the sample shaped a similar variety in their views. Although executives guided corporate culture with their expectations, they were removed from the daily job behaviours of the people below them in the hierarchy. In contrast, non-supervisory employees were often frontline employees who dealt with business partners and customers but lacked an understanding of the "big picture". Middle managers were closely in touch with the activities of the people they supervised and were more likely to understand both the "big picture" and the specific 
activities needed to achieve it on an individual level. Thus, averages were calculated for different positions, but with special consideration of the opinion of middle management. The three perspectives also provided the ability to triangulate the data.

We retained items if participants considered the actions within their control and we discarded those that were not phrased clearly at the individual level, or items that reflected department level responsibilities instead of personal responsibilities. The purification process resulted in the retention of 26 items from the original list of 71 items.

Purification Pretest \#2: Academic Researchers. A second pretest of the scale considered the opinion of 64 internationally published market orientation researchers. These researchers were solicited via email for their advice on the face and content validity of the 26 remaining items. Seventeen responses (27\%) were received, from researchers spanning eight countries and four continents. Four researchers were from Europe, four from Australia and New Zealand, eight from North America, and one from Asia.

The experts were sent a formatted scale and asked to provide open-ended feedback on the appropriateness of the instrument. Feedback from the researchers was used to remove or alter items that were worded vaguely or appeared to be motherhood statements. Per their suggestions, terms specifying a frequency of behavior (i.e., once per year) were removed because the frequencies were usually artifacts of previous scales, and 


\section{Running Head: Developing the I-MARKOR}

appeared arbitrary in this research. Additionally, industry-specific wording was carefully reviewed for clarity and consistency.

We considered suggestions to both discriminate from or to include other measures. In this area, there was diversity of opinion. Experts diverged on whether to build upon previous organizational or individual level scales. At this stage, items from the Selling Orientation - Customer Orientation scale, developed by (Saxe and Weitz 1982) were compared and some concepts integrated into the final scale. For example, "Try to help distributors achieve their goals" was added to the scale. In all, expert feedback eliminated 6 items and created a 20 item scale.

Purification Pretest \#3: Second Practitioner Review. Next, five financial services distributors reviewed the instrument and confirmed its clarity and meaningfulness to financial services employees. A distributor perspective also provided valuable insights because as marketers and sales people, they focused upon the customer. This review resulted in the rephrasing of the scale response categories for more meaningful discrimination as recommended by Viswanathan (2004). Original response anchors were: 1) not at all; 2) slightly; 3) somewhat; 4) moderately; 5) to a great extent. Participants suggested five meaningful categories: 1) never; 2) almost never; 3) sometimes; 4) often; 5) almost always.

Phase 1 item retention decisions were made using input from practitioner and academic experts, resulting in the deletion of 45 items. This approach resulted in a theory 


\section{Running Head: Developing the I-MARKOR}

driven construct and built upon the dimensions established in the market orientation literature. The processes also relied heavily on assessment of both content and face validity. Next, we describe Phase 2 data collection, including an assessment of scale validity and reliability and confirmation of its psychometric properties.

Phase 2 Data Collection

Sample. The study involved a cross-section of North American insurance and financial services companies. Insurance association membership lists that were accessed through the Internet provided contact information for a cross-section of employees across more than 50 North American insurance and financial services companies. The Canadian sampling frame included members of the Canadian Life Underwriters Association (CLU) and LOMA (FLMI Society). The U.S. sampling frame included members of the North American Health Underwriters Association (NAHU), Insurance Accounting and Technology Professionals (IATP), Group Underwriters Association of America (GUAA), and the Society of Financial Service Professionals (SFSP). These groups were chosen because they were large organizations focused on a wide range of positions in the financial services industry with varying roles and frequencies of customer and distributor contact.

The survey data were collected via an online website and produced a response rate of 138 useable responses from a sample of 814 or $17 \%$. As the survey response rate 
was less than $40 \%$, actions were undertaken to eliminate concerns of potential nonresponse bias (Lambert and Harrington 1990). Analysis of the demographics and means of the first to second waves of responses did not reveal significant differences between waves and mitigated concern for non-response bias (Creswell 1994; Lambert and Harrington 1990).

Using SPSS software, Exploratory Factor Analysis reduced the Market Orientation construct into a clearer factor structure (Hair et al. 1998) and identified items with common variance (Rossiter 2002). Findings with regard to the correlation matrix warranted factor analysis, for example, using Bartlett's test of sphericity, the approximate Chi-Square was 1734.437, df 190, sig. 0.00. Additionally, the Kaiser-Meyer-Olkin Measure was 0.925 and the Measures of Sampling Adequacy (M.S.A.) for each item were all greater than .86 without excessive inter-item correlation values.

As previous researchers of organizational level market orientation had identified a multidimensional construct with inter-correlated factors (e.g., Kohli et al. 1993), factors were extracted using Principal Axis Factoring and an oblique rotation. Three factors were identified for the I-MARKOR scale dominated by the first factor, information acquisition. These factors closely mirrored factors observed at the organizational level; specifically information acquisition, information dissemination and strategic response.

Confirmatory Factor Analysis. In addition to methods advocated by Churchill (1979), Confirmatory Factor Analysis (CFA) (using maximum likelihood) was 
undertaken to examine the stability of the factor structures identified in the EFA and to provide information for measure refinement (Hinkin 1995). Using CFA, Table 1 compares the expected three-dimensional model to the two-factor model, to a singlefactor first order model, and to a single-factor second order model with three dimensions. Fit indices confirmed that the three-factor model and the second order one-factor models fit the data better than the first order one factor model. The second order factor and the three factor model had identical fit statistics. The CMIN/df for the three-factor and second order latent factor fell below 2, as recommended by Hair, Anderson, Tatham, and Black (1998). The Comparative Fit Index (CFI) indicates a well-fitting model for the three-factor (CFI >.9). Similarly, the RMSEA for the three-factor model meets the requirements for a reasonable fit to the population (RMSEA less than .08).

These results support the presence of a latent construct with three dimensions. The second order three dimensional construct showed the same fit as the first order three factor model. Theory supports a second order model over a first order because individuals in different roles may experience different levels of market orientation on each of the three dimensions, so that if a role focuses upon information acquisition, then it may not have as much to do with strategic response. However, the individual may still be considered highly market-oriented based on information acquisition accountabilities. Therefore a second order construct better reflects individual differences in market oriented activities. The measurement model statistics (depicted in Table 2) demonstrate that market-oriented behavior explains a large amount of the variation in the three factors 


\section{Running Head: Developing the I-MARKOR}

of information acquisition (IA, $\mathrm{r}^{2}=.79$ ), information sharing (IS, $\mathrm{r}^{2}=.81$ ) and strategic response $\left(\mathrm{SR}, \mathrm{r}^{2}=.48\right)$

Take in Tables I and II

Construct Reliability. As Hinkin (1995) noted, reliability is a pre-condition for validity. The scale reliability was $\alpha=.9409$ for the 20 items comprising the entire individual market orientation scale. Cronbach's alpha was assessed for each dimension because the composite market orientation measure was multidimensional. Scale reliabilities were $\alpha=.9250$ Information Acquisition, $\alpha=.8370$ for Strategic Response and $\alpha=.8864$ for Information Sharing.

Psychometric Properties. This research posits several reasons for market-oriented actions at the individual level, based upon customer contact and learning agility. Thus, the study also collected information regarding these constructs conceptually linked to the I-MARKOR. Learning agility was measured using a 7-item learning agility instrument used to screen candidates for an executive masters degree. Cronbach's alpha for the learning agility scale was $\alpha=.72$, and exceeded minimum standards of $\alpha>.70$ established by Nunnally (1976). No scale items were discarded, as the item-to-total correlations were optimal. Distance from the customer was measured by averaging the frequency of contact with both distributors and premium payers. 
Convergent and Discriminant Validity. As expected, study results calculated strong correlations between the individual market oriented behavior scale and validation items measuring general customer focus. This confirmation of expected relationships supports convergent validity. Additionally, we computed the variance extracted estimate (AVE), which measures the amount of variance captured by a construct in relation to the variance due to random measurement error (Fornell and Larcker 1981). Table 3 includes the AVE's and the squared correlations for each factor. All AVE's exceeded the suggested levels for convergent validity (i.e., .50 as recommended by Fornell and Larcker 1981). The AVE's for each factor were also greater than the squared interfactor correlations, hence indicating discriminant validity (Fornell and Larcker 1981). Additionally the discriminant validity of each factor is evidenced by each indicator loading higher on the factor of interest than on any other variable.

Take in Table III

Nomological Validity. Our findings also support nomological validity. Table 4 indicates that all three dimensions of the I-MARKOR significantly correlated with the frequency of customer and distributor contact, and with employee learning agility. That is, the more frequently the employee interacts with distributors or customers, and the higher the learning agility of the employee, the more likely the employee is to actively acquire and share information, and to assist in the development of a strategic response. 
Take in Table IV

\section{DISCUSSION}

The research results provide a rich topic of discussion. The following section analyzes delivery of research objectives, and highlights areas of interest arising from the exploratory study, the confirmatory study, and measure development. Additionally the measure of individual level market orientation developed in this research is compared to the seminal measures of organizational market orientation.

This study undertook to resolve two gaps in the existing market orientation literature. First, the research intended to clarify and strengthen the marketing concept by anchoring it as a measurable dynamic capability in the strategy domain. This expands the focus of the marketing concept from the marketing domain to one of strategic value throughout the organization. The challenge lay in creating a flexible and dynamic instrument useful for measuring competitive market-oriented behaviors relevant to many roles within the service organization.

Second, this research aimed to increase understanding surrounding individual accountability for market-oriented actions. Previous instruments did not measure individual behaviors, and thus were unable to measure whether a market orientation strategy had been successfully adopted across a company. Employees who accept a 


\section{Running Head: Developing the I-MARKOR}

market-oriented strategy will translate it into their own market-oriented attitudes and actions. The following section evaluates research results against objectives.

\section{Market Orientation as a Dynamic Capability}

The I-MARKOR scale is flexible because its development involved multiple and varying perspectives: practitioners and academics, managers and non-supervisory staff, marketing and non-marketing staff, employees and customers. Testing of the IMARKOR measure indicates that employees throughout the financial services industry can understand and identify with its content. The research develops a comprehensive tool that strategy makers and implementers can use for benchmarking and assessment of the success of strategic market orientation initiatives across their own financial services organization.

The second issue concerns whether the I-MARKOR provides a way to measure a dynamic capability. To understand this question, it is important to revisit the concept of a dynamic capability. To measure a dynamic capability, the scale must measure "The firm's processes that use resources - specifically the processes to integrate, reconfigure, gain and release resources - to match and even create market change (Eisenhardt and Martin 2000, p. 1107).” The I-MARKOR scale measures how employees acquire, share and respond to market information. Factor analysis confirmed these three dimensions. The indicators of these dimensions measure good work practices, such as networking and communicating. The items include examples that are worded in a way that is useful 


\section{Running Head: Developing the I-MARKOR}

across jobs and over time. Essentially, scale items constitute "best practices", but the exact methods of each task's execution would vary among respondents. The items that represent market-oriented behaviors translate to many jobs and can be implemented in different ways by different people. Additionally, these represent ways to integrate and reconfigure the important resource of external market information. Therefore, the IMARKOR instrument can be used to measure dynamic capabilities.

The Market Orientation of an Individual

The final objective involved understanding how individuals contribute to the market orientation of a service organization. The scale measures market-oriented behaviors of individuals employed across all functions of a financial services organization. Such an instrument clarifies individual accountabilities and specifies measurable routines that add competitive value. Although previous research informed the development of the I-MARKOR and hypothesized relationships, this involves a significant shift in the accountability for market-oriented actions. The appendix compares Kohli and Jaworski's (1993) organizational level measure with the new individual level measure. The survey questions are clearly phrased to include only personal actions. The use of "I" in each item is clearly different than seminal measures of market orientation. Additionally, the nomological testing of the measure identified a relationship between the market-oriented behavior of individuals and antecedents that reflect personal dispositions and roles. The more frequently the employee interacts with distributors or customers, and the higher the learning agility of the employee, the more likely the employee is to 
actively acquire and share information, and to assist in the development of a strategic response. Of interest, the frequency of customer contact and the learning agility of the employee were uncorrelated. This implies that an organization may foster employee market orientation in different and unrelated ways: by hiring strong learners or by increasing interaction between customers and employees. The confirmation of relationships between individual market orientation and individual level antecedents underscores the difference between organizational and individual market orientation and the value-added of this measure.

The process of measure development identified areas of interest to strategymakers who aim to promote accountability for market-oriented behaviors across the service organization. Next, conclusions from the development of the measure (including exploratory and confirmatory stages) are reviewed.

\section{Measure Dimensionality}

The difference in results highlights the importance of confirmatory analysis when developing a measure. This research is one of a few recent studies to use confirmatory factor analysis to test market orientation as a latent construct (Harrison-Walker 2001; Matsuno and Mentzer 2000). Earlier studies tested a first order three-factor solution and noted strong inter-factor correlations. For example, although Narver and Slater (1990) theorized a uni-dimensional construct with three dimensions, they did not utilize CFA to test this model, instead they used traditional methods to test the three dimensions. 


\section{Running Head: Developing the I-MARKOR}

The three-factor I-MARKOR solution was similar to the conceptualized three factor MARKOR solution at the organizational level (Kohli et al. 1993). The strongest factor was information acquisition, and the weakest was coordination of response. As the measure was developed based upon the three dimensions anchored in the organizational literature, in general, the factors explain the variables as expected.

\section{LIMITATIONS AND FUTURE RESEARCH}

The small sample size constrained the data analysis because the same sample was used to gauge the reliability and facets of validity of measure (Campbell and Fiske (1959) in Churchill 1979). Future researchers must replicate study results and extend its generalization to other service industries, and potentially differing sectors (private and public).

In future research, a sponsoring company would broaden the type of employee who participates, and increase the response rate to the survey. This could extend the current study by allowing the collection of survey data at different times, combating method bias, and permitting longitudinal study of causal relationships that would establish the scale's predictive validity.

Future researchers might measure market orientation with extra-firm respondents. Although the I-MARKOR was developed using both intra-firm and extra-firm respondents, the nomological tests of validity were undertaken with solely intra-firm 


\section{Running Head: Developing the I-MARKOR}

participants (they assessed their own company, and their own actions). It would be of great practical and academic value to gain this insight with extra-firm respondents, as suggested by Harris (2003).

\section{CONTRIBUTIONS}

This study fills a gap relating to the theory and measurement of dynamic capabilities associated with the market orientation of individuals throughout a service organization. In his appraisal of market orientation research, Langerak (2003) concluded that the nature of the link between organizational market orientation and performance has not yet been adequately explained. This suggests that other considerations may shape the success of a market-oriented strategy. This research has described and tested how and why individual employees may perform market-oriented routines underpinning the market orientation of the organization. Consideration of individual in the creation of a customer orientation largely been tested with employees in sales and marketing (e.g., Pettijohn and Pettijohn 2002). In contrast, this research considered employees throughout the company and tested a market orientation - not a marketing orientation.

Extant measures are limited by their use of a single informant (internal to company) (Harris 2003). Therefore, this research has also contributed to understanding of market orientation by developing a measure using multiple informants, including distributors who are external stakeholders in the process, and academic researchers who provide objective insights to the market orientation process. Finally, this research 
contributes as one of a few recent studies to use confirmatory factor analysis to test market orientation as a latent construct (Harrison-Walker 2001; Matsuno and Mentzer 2000).

\section{IMPLICATIONS FOR MANAGERS}

The I-MARKOR provides managers with a way of assessing and measuring employee market-oriented behaviors. Managers can use this scale to implement a scorecard-based approach to performance management. Among other non-monetary measures of performance, the Balanced Scorecard advocates measures that are oriented to customer relationship development. A Balanced Score Card strategy has been widely adopted by organizations who use it to develop and assess the achievement of group level targets (Kaplan and Norton 2001). Recently there has been increased interest in further leveraging human capital through the development of personal score cards (Huselid et al. 2005). Based upon measurable and trainable behaviors, the I-MARKOR can be used by managers as part of this personal scorecard to identify high performers, role models, and training needs. The scale's strong correlation with learning orientation may help to identify and develop high-potential employees; those with the ability to move through and up the service organization without losing touch with the market. This scale may also help to identify service workers for whom the increased customer contact coupled with a strong individual market orientation creates internal benefits such as job satisfaction and commitment (Donavan et al. 2004). 
Additionally, the use of such individual market oriented actions can be used to solicit information to address and defuse channel conflict, potentially a significant issue in the rapidly restructuring financial services industry due to its uneven distribution of power between agents and service providers (Oumlil and Rao 1993).

\section{CONCLUSION}

The I-MARKOR measures market-oriented behaviors of individuals employed across all functions in a financial services context. Such an instrument clarifies individual accountabilities and specifies measurable routines that add competitive value. This scale provides a method to assess differences between individuals within a service-based organization, enabling empirical research on differences between departments, roles, training and other characteristics that may influence the extent to which an individual performs market-oriented behaviors. Such research is important to increase understanding of how service organizations foster market orientation. The I-MARKOR is a useful instrument regardless of whether a researcher or practitioner advocates an emergent or planned market orientation. For example, the I-MARKOR can be used to identify and reward a market orientation emerging through individual efforts. Alternatively, the scale can be used to build a market orientation by identifying gaps and training needs. 


\section{REFERENCES}

Baker, W. E. and Sinkula, J. M. (1999), "The synergistic effect of market orientation and learning orientation on organizational performance," Journal of the Academy of Marketing Science Vol. 27 (4), 411-27.

Ballantyne, D., Christopher, M., and Payne, A. (1995), "Improving the quality of services marketing: Service (re)design is the critical link," Journal of Marketing Management Vol. $11,7-24$.

Bell, B. S. and Kozlowski, S. W. J. (2002), "Interactive effects on self-efficacy, performance and knowledge," Journal of Applied Psychology Vol. 87 (3), 497-505.

Bhuian, S. N. (1997), "Exploring market orientation in banks: An empirical examination in Saudi Arabia," Journal of Services Marketing Vol. 11 (5), 317-28.

Brown, T. J., Mowen, J. C., Donavan, D. T., and Licata, J. W. (2002), "The customer orientation of service workers: Personality trait effects on self-and supervisor performance ratings," Journal of Marketing Research Vol. 39 (1), 110-19.

Caruana, A., Pitt, L., and Ewing, M. (2003), "The market orientation-performance link: The role of service reliability," The Service Industries Journal Vol. 23 (4), 25-41.

Celuch, K. G., Kasouf, C. J., and Strieter, J. C. (2000), "The influence of organizational market orientation on individual-level market-oriented cognitions," Psychology and Marketing Vol. 17 ( 11), 935 - 54.

Cho, D. Y. (2002), "The connection between self-directed learning and the learning organization," Human Resource Development Quarterly Vol. 13 (4), 467-70.

Churchill, G. A. (1979), "A paradigm for developing better measures of marketing constructs," Journal of Marketing Research Vol. XVI (February), 64-73.

Creswell, J. W. (1994), Research Design: Qualitative and Quantitative Approaches. Thousand Oaks: Sage Publications.

Darroch, J. and McNaughton, R. B. (2003), "Beyond market orientation: Knowledge management and the innovativeness of New Zealand firms," European Journal of Marketing Vol. 3/4 (37), 572-93.

Day, G. S. (1994), "The capabilities of market-driven organizations," Journal of Marketing Vol. 58 (4), 37-53. 
Deng, S. and Dart, J. (1994), "Measuring market orientation: A multi-factor, multi-item approach," Journal of Marketing Management Vol. 10, 725-42.

Donavan, D. T., Brown, T. J., and Mowen, J. C. (2004), "Internal benefits of serviceworker customer orientation: Job satisfaction, commitment, and organizational citizenship behaviors," Journal of Marketing Vol. 68, 128-46.

Eisenhardt, K. M. and Martin, J. A. (2000), "Dynamic capabilities: What are they?," Strategic Management Journal Vol. 21 (10-11), 1105-21.

Farrell, M. A. (2000), "Developing a market-oriented learning organisation," Australian Journal of Management Vol. 25 (2), 201-22.

Flynn, L. R. and Pearcy, D. (2001), "Four subtle sins in scale development: Some suggestions for strengthening the current paradigm," International Journal of Market Research Vol. 43 (4), 409-23.

Fornell, C. and Larcker, F. D. (1981), "Evaluating structural equation models with unobservable variables and measurement errors.," Journal of Marketing Research Vol. $18,39-50$.

Fulk, J. (1993), "Social construction of communication technology," Academy of Management Journal Vol. 36, 921-50.

Gerbing, D. W. and Anderson, J. C. (1988), "An updated paradigm for scale development incorporating unidimensionality and its assessment," Journal of Marketing Research Vol. 25 (2), 186-93.

Hair, J. F., Anderson, R. E., Tatham, R. L., and Black, W. C. (1998), Multivariate Data Analysis (Fifth ed.). Upper Saddle River, NJ: Prentice-Hall, Inc.

Han, J. K., Kim, N., and Srivastava, R. K. (1998), "Market orientation and organizational performance: Is innovation a missing link?," Journal of Marketing Vol. 62 (4), 30-45.

Hardesty, D. M. and Bearden, W. O. (2004), "The use of expert judges in scale development: Implications for improving face validity of measures of unobservable constructs," Journal of Business Research Vol. 57, 98-107.

Harris, L. C. (2003), "Measuring market orientation: Exploring a market oriented approach," Journal of Market-Focused Management Vol. 5, 239-70.

---- (2000), "The responses of front-line employees to market-oriented culture change," European Journal of Marketing Vol. 34 (3-4), 318-40.

---- (2002), "Sabotaging market-oriented culture change: An exploration of resistance justification and approaches.," Journal of Marketing Theory and Practice Vol. 10 (3). 
Harris, L. C. and Ogbonna, E. (2001), "Leadership style and market orientation: an empirical study," European Journal of Marketing Vol. 35 (5/6), 744-64.

Harrison-Walker, L. J. (2001), "The measurement of a market orientation and its impact on business performance," Journal of Quality Management Vol. 6 (2001), 139-72.

Helfert, G., Ritter, T., and Walter, A. (2002), "Redefining market orientation from a relationship perspective: Theoretical considerations and empirical results," European Journal of Marketing Vol. 36 (9), 1119-39.

Hinkin, T. R. (1995), "A review of scale development practices in the study of organizations," Journal of Management Vol. 21 (5), 967-88.

Homburg, C. and Pflesser, C. (2000), "A multiple-layer model of market-oriented organizational culture: Measurement issues and performance outcomes," Journal of Marketing Research Vol. 37 (4), 449-62.

Huselid, M. A., Becker, B. E., and Beatty, R. W. (2005), The Workforce Scorecard. Boston: Harvard Business School Publishing Corporation.

Javalgi, R. R. G., Whipple, T. W., Ghosh, A. K., and Young, R. B. (2005), "Market orientation, strategic flexibility, and performance: Implications for services providers," Journal of Services Marketing Vol. 19 (4), 212-21.

Jaworski, B. J. and Kohli, A. K. (1993), "Market orientation: Antecedents and consequences," Journal of Marketing Vol. 57 (3), 53-71.

Kahn, K. B. (2001), "Market orientation, interdepartmental integration, and product development performance," The Journal of Product Innovation Management Vol. 18 (5), 314-23.

Kaplan, R. S. and Norton, D. P. (2001), The strategy-focused organization: How balanced scorecard companies thrive in the new business environment. Boston: Harvard Business School Publishing Corporation.

Kennedy, K. N., Lassk, F. G., and Goolsby, J. R. (2002), "Customer mind-set of employees throughout the organization," Journal of the Academy of Marketing Science Vol. 30 (2), 159-71.

Kohli, A., Jaworski, B., and Kumar, A. (1993), "MARKOR: A measure of market orientation," Journal of Marketing Research Vol. 30, 467-77.

Kohli, A. K. and Jaworski, B. J. (1990), "A market orientation: The construct, research propositions," Journal of Marketing Vol. 54 (2), 1-18. 
Lambert, D. M. and Harrington, T. C. (1990), "Measuring nonresponse bias in customer service mail surveys," Journal of Business Logistics Vol. 11 (2), 5-25.

Langerak, F. (2003), "An appraisal of research on the predictive power of market orientation," European Management Journal Vol. 21 (4), 447-64.

---- (2001), "Effects of market orientation on the behaviors of salespersons and purchasers, channel relationships, and performance of manufacturers," International Journal of Research in Marketing Vol. 18 (3).

Lei, D., Hitt, M. A., and Bettis, R. (1996), "Dynamic core competences through metalearning and strategic context," Journal of Management Consulting Vol. 22 (4), 549-70.

Liu, S. S., Luo, X., and Shi, Y.-Z. (2002), "Integrating customer orientation, corporate entrepreneurship, and learning orientation in organizations-in-transition: an empirical study," International Journal of Research in Marketing Vol. 19 (4), 367-82.

Matsuno, K. and Mentzer, J. T. (2000), "The effects of strategy type on the market orientation-performance relationship," Journal of Marketing Vol. 64 (4), 1-16.

Narver, J. C. and Slater, S. F. (1990), "The Effect of a Market Orientation on Business Profitability," Journal of Marketing Vol. 54 (4), 20-36.

Nelson, R. R. and Winter, S. G. (1982), An Evolutionary Theory of Economic Change. Cambridge, Mass: The Belknap Press of Harvard University Press.

Nunnally, J. C. (1976), Psychometric Theory (Second ed.). New York: McGraw-Hill.

Oumlil, A. B. and Rao, C. P. (1993), "Services marketing: Review and synthesis of critical distribution problems," Journal of Marketing Management Vol. 3 (2), 6-16.

Perkins, A. G. (1994), "The learning mind-set: Who's got it, what it's good for," Harvard Business Review Vol. 72 (2), 11-12.

Pettijohn, C. E. and Pettijohn, L. S. (2002), "The influence of salesperson skill, motivation, and training on the practice of customer-oriented selling," Psychology and Marketing Vol. 19 (9), 743-57.

Piercy, N. F., Harris, L. C., and Lane, N. (2002), "Market orientation and retail operatives' expectations," Journal of Business Research Vol. 55 (4), 261-73.

Rossiter, J. R. (2002), "The C-OAR-SE procedure for scale development in marketing," International Journal of Research in Marketing Vol. 19, 305-35.

Saxe, R. and Weitz, B. A. (1982), "The SOCO scale: A measure of the customer orientation of salespeople," Journal of Marketing Research Vol. 19, 343-51. 
Slater, S. F. and Narver, J. C. (1995), "Market orientation and the learning organization," Journal of Marketing Vol. 59 (3), 63-75.

---- (1999), "Market-oriented is more than being customer-led," Strategic Management Journal Vol. 20 (12), 1165-68.

Teece, D. J., Pisano, G., and Shuen, A. (1997), "Dynamic capabilities and strategic management," Strategic Management Journal Vol. 18 (7), 509-33.

Thornton, J. and White, L. (2001), "Customer orientations and usage of financial distribution channels," Journal of Services Marketing Vol. 15 (3), 168-85.

Van Egeren, M. and O'Connor, S. (1998), "Drivers of market orientation and performance in service firms," Journal of Services Marketing Vol. 12 (1), 39-58.

Vargo, S. L. and Lusch, R. F. (2004), "Evolving to a new dominant logic for marketing," Journal of Marketing Vol. 68, 1-17.

Viswanathan, M., Sudman, S., and Johnson, M. (2004), "Maximum versus meaningful discrimination in scale response: Implications for validity of measurement of consumer perceptions about products," Journal of Business Research Vol. 57, 108-24.

Webster, F. E. (1978), "Management science in industrial marketing," Journal of Marketing Vol. 42, 21-27.

West, G. P. and Meyer, G. D. (1997), "Communicated knowledge as a learning foundation," The International Journal of Organizational Analysis Vol. 5 (1), 25-58.

Williams, M. J. (1997), "Agility in learning: An essential for evolving organizations... and people," Harvard Management Update Vol. 2 (5).

Winter, S. G. (2000), "The satisficing principle in capability learning," Strategic Management Journal Vol. 21 (10-11), 981-96.

Wood, R. and Bandura, A. (1989), "Social cognitive theory of organizational management," Academy of Management Review Vol. 14 (3), 361-84.

Zollo, M. and Winter, S. G. (2002), "Deliberate learning and the evolution of dynamic capabilities," Organization Science Vol. 13 (3), 339-51. 
APPENDIX

(MARKOR : I-MARKOR) Comparison of Organizational to Individual Level Measure

\begin{tabular}{|c|c|}
\hline MARKOR (Kohli and Jaworski, 1993) & I-MARKOR \\
\hline $\begin{array}{l}\text { Information Acquisition } \\
\text { 1. In this organization, we meet with customers at least once a year to } \\
\text { find out what products or services they will need in the future. } \\
\text { 2. In this organization, we do a lot of in-house market research. } \\
\text { 3. We are slow to detect changes in our customers' product } \\
\text { preferences. } \\
\text { 4. We poll end users at least once a year to assess the quality of our } \\
\text { products and services. } \\
\text { 5. We are slow to detect fundamental shifts in our industry (e.g., } \\
\text { competition, technology, regulation). } \\
\text { 6. We periodically review the likely effect of changes in our business } \\
\text { environment (e.g. regulation) on customers. } \\
\text { Information Dissemination } \\
\text { 7. We have interdepartmental meetings at least once a quarter to } \\
\text { discuss market trends and developments. } \\
\text { 8. Marketing personnel in our organization spend time discussing } \\
\text { customers' future needs with other functional departments. } \\
\text { 9. When something important happens to a major customer or market, } \\
\text { the whole organization knows about it in a short period. } \\
\text { 10. Data on customer satisfaction are disseminated at all levels in this } \\
\text { organization on a regular basis. } \\
\text { 11. When one department finds out something important about } \\
\text { competitors, it is slow to alert other departments. } \\
\text { Co-ordination of Strategic Response } \\
\text { 12. It takes us forever to decide how to respond to our competitors' } \\
\text { price changes. }\end{array}$ & $\begin{array}{l}\text { Information Acquisition } \\
\text { 1. I ask distributors to assess the quality of our products and services. } \\
\text { 2. I interact with agencies to find out what products or services } \\
\text { customers will need in the future. } \\
\text { 3. In my communication with distributors, I periodically review the } \\
\text { likely effect of changes in our business environment (e.g., company } \\
\text { mergers and acquisitions) on customers. } \\
\text { 4. I take responsibility to detect fundamental shifts in our industry } \\
\text { (e.g., competition, technology, regulation) in my communication } \\
\text { with distributors. } \\
\text { 5. I talk to or survey those who can influence our customers' } \\
\text { purchases (e.g., distributors). } \\
\text { 6. I review our product development efforts with distributors to ensure } \\
\text { that they are in line with what customers want. } \\
\text { 7. I participate in informal "hall talk" that concerns our competitor's } \\
\text { tactics or strategies. } \\
\text { 8. I collect industry information through informal means (e.g., lunch } \\
\text { with industry friends, talks with trade partners). } \\
\text { Information Dissemination } \\
\text { 9. I participate in interdepartmental meetings to discuss market trends } \\
\text { and developments. } \\
\text { 10. I let appropriate departments know when I find out that something } \\
\text { important has happened to a major distributor or market. } \\
\text { 11. I coordinate my activities with the activities of coworkers or } \\
\text { departments in this organization. } \\
\text { 12. I pass on information that could help company decision-makers to } \\
\text { review changes taking place in our business environment. }\end{array}$ \\
\hline
\end{tabular}


13. For one reason or another we tend to ignore changes in our customers' product or service needs.

14. We periodically review our product development efforts to ensure that they are in line with what customers want.

15. Several departments get together periodically to plan a response to changes taking place in our business environment.

16. If a major competitor were to launch an intensive campaign targeted at our customers, we would implement a response immediately.

17. The activities of the different departments in this organization are well coordinated.

18. Customer complaints fall on deaf ears in this organization.

19. Even if we came up with a great marketing plan, we probably would not be able to implement it in a timely fashion.

20. When we find that customers would like us to modify a product or service, the departments involved make concerted efforts to do so
13. I communicate market developments to departments other than marketing.

14. I communicate with our marketing department concerning market developments.

15. I try to circulate documents (e.g., emails, reports, newsletters) that provide information on my distributor contacts and their customers to appropriate departments

\section{Co-ordination of Strategic Response}

16. I try to bring a customer with a problem together with a product or person that helps the customer to solve that problem.

17. I try to help distributors achieve their goals.

18. I respond quickly if a distributor has any problems with our offerings.

19. I take action when I find out that customers are unhappy with the quality of our service.

20. I jointly develop solutions for customers with members of our customer / advisor relationship team. 


\section{TABLE I}

Comparisons of Fit Statistics for Measurement Model

\begin{tabular}{|l|l|l|l|l|l|l|}
\hline Model & $\chi^{2}$ & df & CMIN & $p$ & CFI & RMSEA \\
\hline $\begin{array}{l}2^{\text {nd }} \text { Order One } \\
\text { Factor with } \\
\text { Three } \\
\text { Dimensions }\end{array}$ & 287.804 & 167 & 1.72 & .000 & .926 & .073 \\
\hline Two Factor & 396.66 & 169 & 2.34 & .000 & .862 & .099 \\
\hline Three Factor & 287.804 & 167 & 1.72 & .000 & .926 & .073 \\
\hline $\begin{array}{l}1^{\text {st }} \text { Order MO } \\
\text { Factor }\end{array}$ & 507.14 & 170 & 2.98 & .000 & .792 & .120 \\
\hline
\end{tabular}




\section{TABLE II}

Standardized Regression Weights for Market-oriented Behaviors

\begin{tabular}{|llll|}
\hline \multicolumn{1}{|c}{ Dimension } & \multicolumn{1}{c}{ Latent } & Estimate & P Value \\
\hline Information Acquisition & Market_Orientation & .887 & .000 \\
Information Sharing & Market_Orientation & .899 & .000 \\
Strategic Response & Market_Orientation & .692 & .000 \\
\hline \multicolumn{1}{|c}{ Item } & \multicolumn{1}{c}{ Dimension } & Estimate & P Value \\
\hline Item 1 & Information Acquisition & .825 & .000 \\
Item 2 & Information Acquisition & .850 & .000 \\
Item 3 & Information Acquisition & .793 & .000 \\
Item 4 & Information Acquisition & .684 & .000 \\
Item 5 & Information Acquisition & .805 & .000 \\
Item 6 & Information Acquisition & .805 & .000 \\
Item 7 & Information Acquisition & .684 & .000 \\
Item 12 & Information Acquisition & .788 & .000 \\
Item 8 & Information Sharing & .722 & .000 \\
Item 9 & Information Sharing & .706 & .000 \\
Item 10 & Information Sharing & .800 & .000 \\
Item 11 & Information Sharing & .800 & .000 \\
Item 13 & Information Sharing & .780 & .000 \\
Item 14 & Information Sharing & .476 & .000 \\
Item 16 & Information Sharing & .788 & .000 \\
Item 15 & Strategic Response & .724 & .000 \\
Item 17 & Strategic Response & .695 & .000 \\
Item 18 & Strategic Response & .760 & .000 \\
Item 19 & Strategic Response & .716 & .000 \\
Item 20 & Strategic Response & .672 & .000 \\
\hline
\end{tabular}

* See Appendix for item wording

$\chi^{2}=287.804$

$\mathrm{df}=167$

$\mathrm{CMIN}=1.72 \mathrm{P}=0.000$

$\mathrm{CFI}=0.926$

RMSEA $=0.073$ 


\section{TABLE III}

Average Variance Extracted and Squared Correlations

\begin{tabular}{|l|r|r|r|r|}
\hline & AVE & $\begin{array}{c}\text { Information } \\
\text { Acquisition }\end{array}$ & $\begin{array}{c}\text { Information } \\
\text { Sharing }\end{array}$ & $\begin{array}{c}\text { Strategic } \\
\text { Response }\end{array}$ \\
\hline $\begin{array}{l}\text { Information } \\
\text { Acquisition }\end{array}$ & .612 & & & \\
$\begin{array}{l}\text { Information } \\
\text { Sharing } \\
\text { Strategic } \\
\text { Response }\end{array}$ & .556 & .53 & & \\
\hline
\end{tabular}




\section{Running Head: Developing the I-MARKOR}

\section{TABLE IV}

Pearson Correlations and Scale Reliabilities (Cronbach alphas noted on diagonal)

\begin{tabular}{|c|c|c|c|c|c|}
\hline & $\begin{array}{c}\text { Customer } \\
\text { Contact } \\
\text { Frequency }\end{array}$ & $\begin{array}{l}\text { Information } \\
\text { Acquisition }\end{array}$ & $\begin{array}{c}\text { Information } \\
\text { Sharing }\end{array}$ & $\begin{array}{l}\text { Strategic } \\
\text { Response }\end{array}$ & $\begin{array}{l}\text { Learning } \\
\text { Agility }\end{array}$ \\
\hline \multicolumn{6}{|l|}{ Customer } \\
\hline Contact & $\mathrm{n} / \mathrm{a}$ & & & & \\
\hline Frequency & & & & & \\
\hline Information & $.398(* *)$ & .9250 & & & \\
\hline $\begin{array}{l}\text { Acquisition } \\
\text { Information }\end{array}$ & & & & & \\
\hline Sharing & $.368(* *)$ & $.728(* *)$ & .8864 & & \\
\hline $\begin{array}{l}\text { Strategic } \\
\text { Response }\end{array}$ & $.189(*)$ & $.561(* *)$ & $.556(* *)$ & .8370 & \\
\hline $\begin{array}{l}\text { Learning } \\
\text { Agility }\end{array}$ & .124 & $.311(* *)$ & $.252(* *)$ & $.261(* *)$ & .7191 \\
\hline
\end{tabular}

** Correlation is significant at the 0.01 level (1-tailed).

* Correlation is significant at the 0.05 level ( 1 -tailed). 
Running Head: Developing the I-MARKOR 